\title{
PENETAPAN KADAR PARASETAMOL, KAFEIN DAN PROPIFENAZON SECARA SIMULTAN DALAM SEDIAAN TABLET DENGAN METODE KCKT
}

\author{
Endhah Yulyarti, Yusnita Rifai, dan Risfah Yulianty \\ Fakultas Farmasi, Universitas Hasanuddin, Makassar
}

Kata Kunci :

presisi, akurasi, kromatografi cair kinerja tinggi (KCKT), parasetamol, kafein, propifenazon, tablet

\section{ABSTRAK}

Parasetamol, kafein dan propifenazon dikombinasikan bersama dalam sediaan obat untuk memberikan efek analgetik. Penggunaan kombinasi obat semakin meningkat untuk mencapai efek terapi yang lebih baik dan penurunan toksisitas sehingga sangat penting untuk mengawasi kandungan zat aktif dalam formulasi farmasetik. Desain penelitian adalah eksperimental menggunakan metode Kromatografi Cair Kinerja Tinggi (KCKT) dengan detektor UV pada $273 \mathrm{~nm}$, kolom ODS, fase gerak metanol dan air (50:50), laju alir $0,6 \mathrm{~mL} / \mathrm{menit}$ dan volume penyuntikan $20 \mu \mathrm{L}$. Pada penelitian ini dilakukan uji kesesuaian sistem, serta penentuan presisi dan akurasi metode analisis. Hasil penelitian diperoleh uji kesesuaian sistem memenuhi syarat dengan standar deviasi relatif (RSD) waktu retensi dan luas puncak ketiga analit $<2 \%$, dengan waktu retensi parasetamol, kafein dan propifenazon masing-masing pada 5,41,6,33 dan 24,11 menit. Rata-rata hasil penentuan presisi parasetamol, kafein dan propifenazon berturut-turut sebesar 94,461 $\pm 1,687 ; 94,642 \pm 1,768$; dan 99,177 $\pm 1,871 \%$ yang memenuhi persyaratan USP $(90-110 \%)$ dengan RSD presisi 1,79; 1,87 dan 1,89\% yang memenuhi kriteria penerimaan $(\leq 2 \%)$. Rerata hasil akurasi parasetamol, kafein dan propifenazon menggunakan kadar 80, 100 dan 120\% yaitu $99,732 \pm 0,949 ; 101,260 \pm 1,331$ dan 99,700 $\pm 1,506 \%$ memenuhi persyaratan rekoveri yaitu 98-102\% untuk parasetamol dan kafein serta $97-103 \%$ untuk propifenazon. Berdasarkan hasil presisi dan akurasi maka metode penetapan kadar parasetamol, kafein dan propifenazon secara simultan menggunakan KCKT memenuhi persyaratan.

\section{PENDAHULUAN}

Pada era saat ini, peredaran berbagai bentuk sediaan kombinasi obat telah mengalami banyak peningkatan. Kombinasi obat dalam suatu sediaan memberikan potensi dan aksi obat yang makin meningkat sehingga mampu meringankan sakit dengan lebih cepat serta efek samping lebih sedikit (1).

Parasetamol adalah obat analgetik antipiretik yang populer dan tersedia dalam berbagai bentuk sediaan farmasetik baik secara tunggal maupun kombinasi dengan obat lain seperti kafein. Kafein merupakan alkaloid derivat xantin yang terdapat dalam produk alam dan seringkali digunakan dalam terapi dengan kombinasi bersama obat antiinflamasi non-steroid pada formulasi analgetik (2).

Sediaan obat yang mengandung kombinasi parasetamol, kafein dan propifenazon banyak ditemukan di pasaran seperti tablet Saridon ${ }^{\circledR}$ dan Bodrex migra ${ }^{\circledR}$, dengan indikasi yaitu memberikan efek analgetik dan antipiretik pada sakit kepala dan flu. Penggunaan obat ini semakin meningkat, sehingga sangat penting untuk mengawasi kandungannya dalam formulasi farmasetik untuk menjamin pencapaian efek terapi yang lebih baik dan penurunan toksisitas $(2,3)$.

Kombinasi obat dalam sediaan multikomponen harus memenuhi persyaratan mutu, efikasi dan keamanan, yang dapat dilakukan dengan beberapa analisis, salah satunya penentuan kuantitatif kadar obat dalam sediaan untuk memastikan obat mengandung jumlah yang sesuai etiket agar dapat memberikan efek yang diinginkan (1).
Kromatografi cair kinerja tinggi (KCKT) seringkali digunakan untuk analisis penetapan kadar obat dalam sediaan kombinasi dengan tujuan efektivitas waktu pada saat pemisahan dan ekstraksi, selain itu penggunaan reagen yang minimal untuk hasil yang lebih akurat dan presisi (1).

Saat ini metode KCKT secara simultan belum tersedia dalam farmakope untuk penetapan kadar campuran parasetamol, kafein dan propifenazon. Metode yang tersedia terbatas hanya untuk pengujian tunggal parasetamol, kafein, propifenazon dan pengujian kombinasi parasetamol dan kafein.

Analisis parasetamol, kafein dan propifenazon secara simultan menggunakan KCKT telah diteliti oleh Delvadiya dkk (2014) tetapi sulit diterapkan dalam analisis rutin karena menggunakan standar internal rasagilin yang tidak tersedia di pasaran dan hasil uji kesesuaian sistem tidak memenuhi persyaratan karena tailing faktor kafein $>2$. Demikian halnya dengan Adupa dkk (2014), menggunakan rentang konsentrasi linieritas yang tidak sesuai kadar parasetamol, kafein dan propifenazon dalam sediaan serta penggunaan $\mathrm{pH}$ yang meragukan $(4,5)$.

Berdasarkan hal tersebut, perlu dilakukan penetapan kadar parasetamol, kafein dan propifenazon secara simultan dalam sediaan tablet dengan metode KCKT, untuk memperoleh metode analisis yang presisi dan akurat serta dapat digunakan dalam analisis kadar parasetamol, kafein dan propifenazon. 


\section{METODE PENELITIAN}

\section{Alat dan Bahan}

HPLC LC 20 AD autosampler Shimadzu ${ }^{\circledR}$, ultrasonik Elma ${ }^{\circledR}$ timbangan analitik Mettler Toledo ${ }^{\circledR}$, timbangan mikrogram Sartorius ${ }^{\circledR}$, kolom okta desilsilan (ODS) YMC ${ }^{\circledR}(5 \mu \mathrm{m}, 250 \mathrm{~mm}$ x 4.6mm), kolom ODS C18 Luna Phenomenex ${ }^{\circledR}(5 \mu \mathrm{m}, 250 \mathrm{~mm}$ $\mathrm{x} 4.6 \mathrm{~mm}), \mathrm{pH}$ meter Mettler Toledo ${ }^{\circledR}$ Seven Compact, seperangkat penyaring Millipore ${ }^{\circledR}$, pompa vakum Millipore ${ }^{\circledR}$

Tablet multikomponen, parasetamol Baku Pembanding Farmakope Indonesia (BPFI), propifenazon BPFI, kafein BPFI diperoleh dari Pusat Pengujian Obat dan Makanan Nasional (PPOMN), air steril Widatra ${ }^{\circledR}$, metanol untuk KCKT Merck ${ }^{\circledR}$, asam fosfat $1 \% \operatorname{Merck}^{\circledR}$, kertas saring Whatman ${ }^{\circledR}$, membran filter Omnipore Merck ${ }^{\circledR}$, syringe filter $0,45 \mu \mathrm{m}$ Advantec ${ }^{\circledR}$ dan seperangkat alat gelas

\section{Teknik Pengumpulan Data}

Data yang diperoleh berupa gambar kromatogram dan ringkasan waktu retensi, area, jumlah plat teoritis, tailing faktor dan resolusi masing masing analit secara simultan.

\section{Teknik Analisis}

Analisis uji kesesuaian sistem (UKS) dilakukan dengan menghitung RSD waktu retensi dan RSD area. Jika diperoleh RSD waktu retensi dan area baku $\geq 2,0 \%$, jumlah plat teoritis $\geq 2000$, tailing faktor $\leq 2$, dan resolusi $>2$ maka analisis dinyatakan memenuhi syarat.

Kadar yang diperoleh dari hasil penentuan presisi dihitung persen RSD, jika nilai yang diperoleh $\leq 2 \%$ maka uji presisi dinyatakan memenuhi syarat:

$$
R S D(\%)=\frac{S D}{x_{\text {rerata }}} \times 100 \%
$$

Nilai recovery dari penentuan akurasi dihitung sebagai berikut:

$$
\% \text { Recovery }=\frac{\text { Berat Baku Diperoleh }}{\text { Berat Baku yang Sebenarnya }} \times 100 \%
$$

jika nilai recovery parasetamol dan propifenazon 98-102\% dan nilai recovery kafein 97-103\%, maka uji akurasi dinyatakan memenuhi syarat

\section{Pembuatan Fase Gerak}

Pada penelitian ini digunakan fase gerak campuran metanol dan air pH 3 dengan perbandingan 50:50.

\section{Penyiapan Sampel}

Sampel sebanyak 20 tablet ditimbang kemudian bobot ratarata dihitung. Setelah dihaluskan, serbuk sampel ditimbang, ditambahkan fase gerak dikocok, dicukupkan hingga $50 \mathrm{~mL}$ dan disaring. Filtrat dipipet $2 \mathrm{~mL}$ dan dicukupkan volumenya hingga $20 \mathrm{~mL}$ dengan fase gerak kemudian disaring menggunakan penyaring membran dengan porositas 0,45 $\mu \mathrm{m}$.

\section{Kondisi Analisis}

Penetapan dilakukan menggunakan KCKT detektor UV pada panjang gelombang $273 \mathrm{~nm}$ dengan kolom ODS Luna phenomenex, fase gerak metanol dan air pH $3(50: 50 \mathrm{v} / \mathrm{v})$, suhu oven $35^{\circ} \mathrm{C}$, laju alir $0,6 \mathrm{~mL} / \mathrm{menit}$, volume penyuntikan $20 \mu \mathrm{L}$.

\section{Uji Kesesuaian Sistem}

Pada uji kesesuaian sistem digunakan larutan baku yang disuntikkan ke dalam KCKT sebanyak 5 kali kemudian siamati luas puncak, waktu retensi, resolusi, tailing faktor dan jumlah plat teoritis.

Presisi

Penetapan presisi dilakukan menggunakan larutan baku dan larutan uji (10 replikasi) yang disuntikkan ke dalam KCKT dan luas puncak diamati kemudian nilai RSD dihitung.

\section{Akurasi}

Metode adisi digunakan pada penetapan akurasi dengan penambahan baku pada larutan uji sehingga diperoleh kadar total $80,100,120 \%$ dari kandungan yang tersedia. Larutan uji dan larutan baku dibuat dan disuntikkan ke dalam KCKT dengan kondisi yang sesuai. Masing-masing kadar dilakukan 3 replikasi.

\section{HASIL DAN PEMBAHASAN}

Pada tahap awal penelitian ini dilakukan optimasi pemisahan parasetamol, kafein dan propifenazon. Optimasi yang maksimal diperoleh dengan menggunakan fase gerak metanol dan air pH 3,0 (50:50) laju alir 0,6 mL/menit menghasilkan pemisahan parasetamol, kafein dan propifenazon terlihat pada kromatogram baku campuran Gambar 1 yang menunjukkan waktu retensi parasetamol, kafein dan propifenazon adalah 5,409; 6,326 dan 24,102 menit dengan nilai resolusi antara dua puncak adalah 3,5 sesuai dengan nilai yang dipersyaratkan lebih dari 2,0.

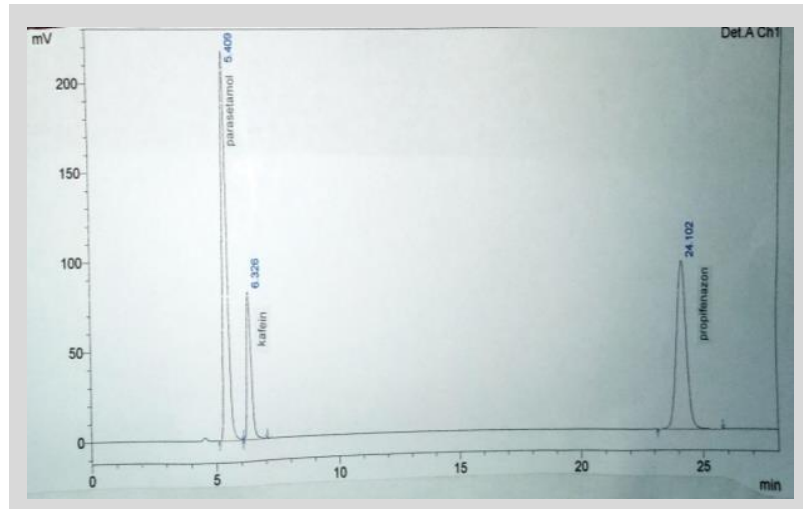

Gambar 1. Kromatogram pemisahan parasetamol, kafein dan propifenazon dengan fase gerak metanol-air $\mathrm{pH} 3(50: 50), \lambda 273 \mathrm{~nm}$, laju alir $0,6 \mathrm{~mL} / \mathrm{menit}$

Tabel 1. Hasil uji kesesuaian sistem parasetamol, kafein dan propifenazon

\begin{tabular}{lccc}
\hline \multicolumn{1}{c}{ Parameter } & PCT & KAF & PP \\
\hline $\begin{array}{l}\text { Waktu retensi } \\
\text { (menit) }\end{array}$ & 5,408 & 6,326 & 24,107 \\
$\begin{array}{l}\text { RSD waktu } \\
\text { retensi (\%) }\end{array}$ & 0,018 & 0,017 & 0,025 \\
$\begin{array}{l}\text { Luas } \\
\text { puncak }\end{array}$ & 2681678 & 996971 & 2707378 \\
$\begin{array}{l}\text { RSD luas puncak } \\
\text { (\%) } \\
\text { Plat }\end{array}$ & 1,115 & 1,281 & 0,335 \\
$\begin{array}{l}\text { Teoritis } \\
\begin{array}{l}\text { Tailing } \\
\text { faktor }\end{array}\end{array}$ & 4411,076 & 6378,757 & 17155,705 \\
$\begin{array}{l}\text { Resolusi } \\
\text { Keterangan: PCT = Parasetamol; KAF = Kafein; PP = Propifenazon }\end{array}$ & 1,336 & 1,093 \\
\end{tabular}

Analisis selanjutnya dilakukan uji kesesuaian sistem dengan menyuntikkan larutan baku campuran sebanyak 5 kali ke dalam KCKT. Parameter uji kesesuaian sistem harus memenuhi kriteria keberterimaan yang akan memberikan 
tingkat kepercayaan mengenai ketepatan kolom, fase gerak, temperatur dan laju alir yang digunakan dan akan menjamin kinerja sistem (pompa dan detektor) (6).

\begin{tabular}{ccccccc}
\multicolumn{2}{l}{$\begin{array}{c}\text { Tabel } \\
\text { 2. Hasil }\end{array}$ penentuan } & presisi & \multicolumn{2}{c}{ parasetamol, kafein dan } \\
\hline \multirow{2}{*}{ No } & \multicolumn{2}{c}{ Parasetamol } & \multicolumn{2}{c}{ Kafein } & \multicolumn{2}{c}{ Propifenazon } \\
\cline { 2 - 7 } & Kadar (mg) & $\begin{array}{c}\text { Kadar } \\
\text { (\%) }\end{array}$ & $\begin{array}{c}\text { Kadar } \\
\text { (mg) }\end{array}$ & $\begin{array}{c}\text { Kadar } \\
\text { (\%) }\end{array}$ & $\begin{array}{c}\text { Kadar } \\
\text { (mg) }\end{array}$ & $\begin{array}{c}\text { Kadar } \\
\text { (\%) }\end{array}$ \\
\hline 1 & 323,587 & 92,453 & 46,037 & 92,073 & 153,787 & 102,525 \\
2 & 325,781 & 93,080 & 46,787 & 93,574 & 149,219 & 99,480 \\
3 & 339,029 & 96,865 & 48,801 & 97,603 & 147,512 & 98,342 \\
4 & 324,945 & 92,841 & 46,698 & 93,397 & 146,562 & 97,708 \\
5 & 331,637 & 94,753 & 48,507 & 97,014 & 147,568 & 98,379 \\
\hline 6 & 340,507 & 97,288 & 47,497 & 94,994 & 152,786 & 101,857 \\
7 & 328,889 & 93,968 & 46,766 & 93,533 & 150,912 & 100,608 \\
8 & 330,732 & 94,495 & 47,260 & 94,521 & 147,044 & 98,029 \\
\hline 9 & 326,274 & 93,221 & 46,816 & 93,632 & 146,113 & 97,408 \\
\hline 10 & 334,765 & 95,647 & 48,039 & 96,078 & 146,153 & 97,435 \\
\hline Rerata & $\mathbf{3 3 0 , 6 1 5}$ & $\mathbf{9 4 , 4 6 1}$ & $\mathbf{4 7 , 3 2 1}$ & $\mathbf{9 4 , 6 4 2}$ & $\mathbf{1 4 8 , 7 6 6}$ & $\mathbf{9 9 , 1 7 7}$ \\
\hline SD & $\mathbf{5 . 9 0 4}$ & $\mathbf{1 . 6 8 7}$ & $\mathbf{0 . 8 8 4}$ & $\mathbf{1 . 7 6 8}$ & $\mathbf{2 . 8 0 6}$ & $\mathbf{1 . 8 7 1}$ \\
\hline RSD & $\mathbf{1 , 7 8 6}$ & $\mathbf{1 , 7 8 6}$ & $\mathbf{1 , 8 6 8}$ & $\mathbf{1 , 8 6 8}$ & $\mathbf{1 , 8 8 6}$ & $\mathbf{1 , 8 8 6}$ \\
\hline & & & & & & \\
\hline
\end{tabular}

Hasil pada Tabel 1 menunjukkan bahwa analisis multikomponen memadai untuk dilakukan pada kondisi dan sistem kromatografi yang digunakan. Hal ini terlihat dari hasil uji kesesuaian sistem yang menunjukkan bahwa RSD waktu retensi dan luas puncak ketiga analit $<2 \%$, jumlah plat teoritis $>2000$, tailing faktor $<2$, dan resolusi antara dua puncak $>2$.

\begin{tabular}{|c|c|c|c|c|c|}
\hline $\begin{array}{c}\text { Level } \\
\text { (\%) }\end{array}$ & $\begin{array}{l}\text { Replikasi } \\
\text { ke- }\end{array}$ & (a) & (b) & $\begin{array}{c}\text { Recovery } \\
\text { (\%) }\end{array}$ & $\begin{array}{c}\text { Rerata } \\
\text { recovery } \\
\text { (\%) }\end{array}$ \\
\hline & & & & a/bx100 & \\
\hline \multirow{3}{*}{80} & 1 & 8,515 & 8,368 & 101,755 & \multirow{3}{*}{100,394} \\
\hline & 2 & 8,445 & 8,368 & 100,924 & \\
\hline & 3 & 8,243 & 8,368 & 98,503 & \\
\hline \multirow{3}{*}{100} & 1 & 10,413 & 10,460 & 99,552 & \multirow{3}{*}{100,158} \\
\hline & 2 & 10,412 & 10,460 & 99,543 & \\
\hline & 3 & 10,604 & 10,460 & 101,378 & \\
\hline \multirow{3}{*}{120} & 1 & 12,536 & 12,552 & 99,874 & \multirow{3}{*}{98,645} \\
\hline & 2 & 12,301 & 12,552 & 98,002 & \\
\hline & 3 & 12,308 & 12,552 & 98,058 & \\
\hline & & Rerata & & & 99,732 \\
\hline
\end{tabular}

\section{(a) = Berat baku diperoleh (mg)}

(b) = Berat baku sebenarnya $(\mathrm{mg})$

Sediaan tablet X yang mengandung parasetamol $350 \mathrm{mg}$ kafein $50 \mathrm{mg}$ dan propifenazon $150 \mathrm{mg}$ digunakan untuk penentuan presisi dengan cara menetapkan kadar analit dalam sediaan sampel, kemudian kadar yang diperoleh dibandingkan dengan kadar dalam sediaan. Penentuan ini menggunakan 10 replikasi.
Persyaratan kadar dalam monografi USP yaitu 90-110\%, sedangkan hasil presisi yang tercantum pada tabel 5 diperoleh kadar parasetamol, kafein dan propifenazon berkisar 92,07-102,52\% yang berarti masih berada dalam kisaran yang dipersyaratkan. Kriteria penerimaan RSD presisi yaitu tidak lebih dari 2\% (7), yang sejalan dengan hasil RSD parasetamol, kafein dan propifenazon masing-masing 1,$79 ; 1,87 ; 1,89 \%$.

\begin{tabular}{|c|c|c|c|c|c|}
\hline $\begin{array}{c}\text { Level } \\
\text { (\%) }\end{array}$ & $\begin{array}{l}\text { Replikasi } \\
\text { ke- }\end{array}$ & (a) & (b) & $\begin{array}{c}\text { Recovery } \\
\text { (\%) }\end{array}$ & $\begin{array}{c}\text { Rerata } \\
\text { recovery } \\
\text { (\%) }\end{array}$ \\
\hline & & & & $\mathrm{a} / \mathrm{b} \times 100$ & \\
\hline \multirow{3}{*}{80} & 1 & 1,198 & 1,193 & 100,476 & \multirow{3}{*}{100,706} \\
\hline & 2 & 1,179 & 1,193 & 98,883 & \\
\hline & 3 & 1,226 & 1,193 & 102,758 & \\
\hline \multirow{3}{*}{100} & 1 & 1,507 & 1,491 & 101,102 & \multirow{3}{*}{100,766} \\
\hline & 2 & 1,512 & 1,491 & 101,391 & \\
\hline & 3 & 1,488 & 1,491 & 99,806 & \\
\hline \multirow{4}{*}{120} & 1 & 1,824 & 1,789 & 101,946 & \multirow{3}{*}{102,308} \\
\hline & 2 & 1,832 & 1,789 & 102,395 & \\
\hline & 3 & 1,835 & 1,789 & 102,581 & \\
\hline & & Rerata & & & 101,206 \\
\hline
\end{tabular}

Penentuan akurasi ditunjukkan dengan persen perolehan kembali atau disebut juga recovery dilakukan untuk mengetahui kedekatan antara nilai yang diperoleh dengan nilai sebenarnya. Ada dua metode yaitu metode simulasi dan adisi, namun metode simulasi tidak dapat digunakan karena komposisi zat tambahan dalam sediaan tablet yang digunakan tidak diketahui sehingga digunakan penambahan baku (metode adisi Perbandingan penambahan sampel terhadap baku adalah 70:30, kemudian dianalisis dan ditentukan berapa persen analit yang ditambahkan tadi dapat ditemukan. Digunakan 3 replikasi pada level 80, 100 dan 120 $\%$ dari kandungan analit dalam tablet (7).

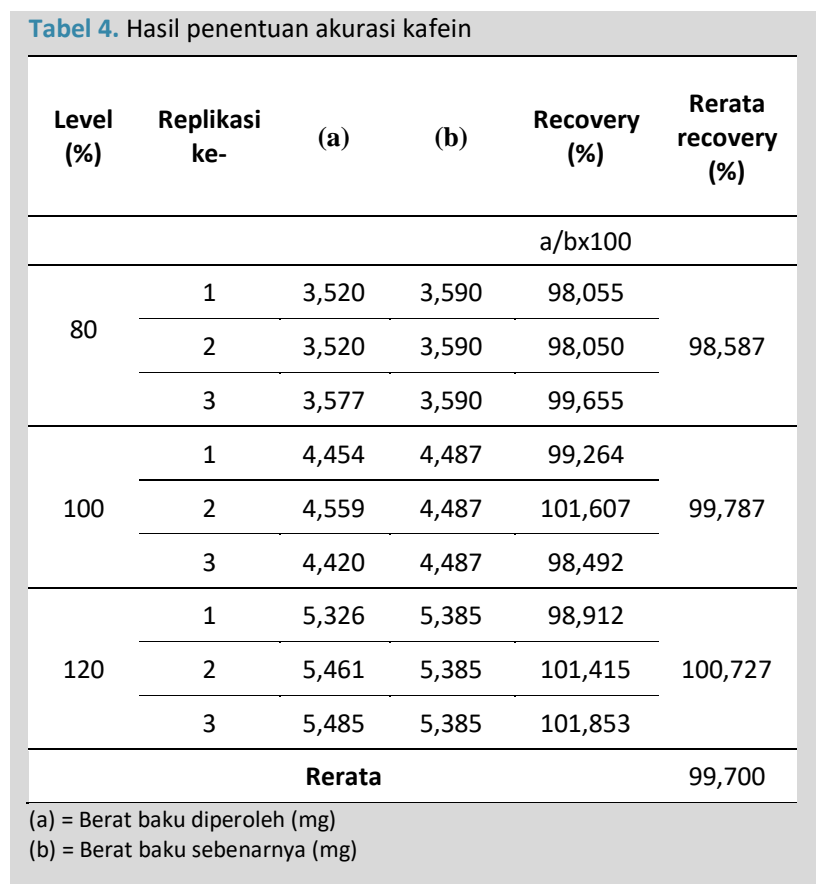

Hasil penentuan akurasi pada tabel 3, 4 dan 5 diperoleh kadar rerata parasetamol, kafein dan propifenazon masing-masing 
99,732; 101,260; 99,700\% sehingga memenuhi persyaratan recovery berturut-turut yaitu 98-102; 97-103 dan 98-102\%.

\section{KESIMPULAN}

Berdasarkan hasil presisi dan akurasi metode yang diperoleh maka dapat disimpulkan bahwa penetapan kadar parasetamol, kafein dan propifenazon dalam sediaan tablet menggunakan KCKT dapat dilakukan secara simultan dan memenuhi syarat keberterimaan uji presisi, akurasi sehingga dapat digunakan untuk analisis. Penetapan kadar parasetamol, kafein dan propifenazon dalam sediaan tablet secara simultan perlu dilakukan dengan metode yang berbeda dan membandingkan signifikansi hasil yang diperoleh

\section{DAFTAR PUSTAKA}

1. Chaudhary, J., Jain A., and Saini, V. 2011. Simultaneous Estimation of Multicomponent Formulations by UV-Visible Spectroscopy: An Overview. International Research Journal of Pharmacy. 2(12), 81-83.

2. Tsvetkova, B.G., Kostova, B.D., Rachev, D.R. Pelkova, L.P. and Pencheva, I.P. 2013. HPLC Assay and Stability Studies of Tablets Containing Paracetamol and Caffeine. International Journal of Pharmaceutical Sciences Review and Research. 18 (1) : 138-142.

3. Ikatan Sarjana Farmasi Indonesia. 2002. Informasi Spesialite Obat Indonesia. Edisi XXXVI. Jakarta. 47, 218

4. Adupa, S., Adupa, S., Simhadri, H., and Kalidindi, S. V. 2014. Simultaneous Estimation of Paracetamol Caffeine and Propyphenazone in Bulk and Pharmaceutical Dosage Form by RP-HPLC. Journal of Pharmacy Research, 8 (3) : 331-335.

5. Delvadiya, K., Kabra, P. Kimbahune, R. Patel, N. and Nargund, L. 2013. High-performance Liquid Chromatographic Determination of Paracetamol, Propyphenazone, and Caffeine in Pharmaceutical Formulations. Indian Journal of Pharmaceutical Education and Research, $47(4): 65-72$
6. Yuwono, M., Indrayanto, G. 2005. Validation of Chromatographic Method of Analysis. Profiles of Drug Substances, Excipients, and Related Methodology. 32 : 243-259.

7. Harmita. 2004. Petunjuk Pelaksanaan Validasi Metode dan Cara Perhitungannya. Majalah Ilmu Kefarmasian. 1 (3) : 117-135

8. Ahuja, S., and Dong, M.W. Eds. 2005. Handbook of Pharmaceutical Analysis by HPLC. 1st Edition. United Kingdom : Elsevier Inc. 191-217, 401-412.

9. Ditjen POM. 1995. Farmakope Indonesia. Edisi IV. Departemen Kesehatan Republik Indonesia. Jakarta.

10. Gupta, V., Jain, A. D. K., Gill, N. S. and Gupta, K. 2012. Development and Validation of HPLC Method. International Research Journal of Pharmaceutical and Applied Sciences. 2 (4) : 17-25.

11. Huber, L. 2007. Validation and Qualification in Analytical Laboratories. 2nd edition. Informa Healthcare USA Inc.125, 141, 144, 146.

12. Kar, A. 2005. Pharmaceutical Drug Analysis Revised 2nd edition. New Age International Publisher. 455

13. Kazakevich, Y., and Lobrutto, R. Eds. 2007. HPLC for Pharmaceutical Scientists. Wiley-Interscience. A John Wiley \& Sons Inc. 417

14. Kupiec, T. 2004. Quality-Control Analytical Methods: High-Performance Liquid Chromatography. International Journal of Pharmaceutical Compounding. 8 (3) : 223-226.

15. Moffat, A. C., Osselton, M. D. and Widdop, B. 2005. Clarke's Analysis of Drug and Poisons. Pharmaceutical Press.

16. Ravisankar, P., Navya, C. N., Pravallika, D., and Sri, D. N. 2015. A Review on Step-by-Step Analytical Method Validation. International Organization of Scientific Research (IOSR) Journal of Pharmacy. 5 (10) : 7-19.

17. Riyanto. 2002. Validasi dan Verifikasi Metode Uji : Sesuai dengan ISO/IEC 17025 Laboratorium Pengujian dan Kalibrasi. Deepublish. 18, 39.

18. United States Pharmacopeial Convention. 2016. The United States Pharmacopeia 39-National Formulary 34 (USP39-NF34). 39th Edition. Rockville USA. United States Pharmacopeial Convention Inc. 6-10<621>, $1-5<1225>$

19. Watson, D. G. Eds. Terjemahan Winny R. Syarief. 2009. Analisis Farmasi : Buku Ajar untuk Mahasiswa Farmasi dan Praktisi Kimia Farmasi. EGC. 314. 